\title{
Infection Status with Metagonimus spp. Metacercariae in Fishes from Seomjin-gang and Tamjin-gang in Republic of Korea
}

\author{
Woon-Mok Sohn",*, Byoung-Kuk Na1, Shin-Hyeong $\mathrm{Cho}^{2}$, Jung-Won Ju², Cheon-Hyeon Kim³ ${ }^{3}$ Ki-Bok Yoon ${ }^{4}$ \\ 'Department of Parasitology and Tropical Medicine, and Institute of Health Sciences, Gyeongsang National University College of Medicine, Jinju \\ 52727, Korea; ' $D i v i s i o n$ of Vectors and Parasitic Diseases, Centers for Disease Control and Prevention, Osong 28159, Korea; ${ }^{3}$ Division of \\ Microorganism, Jeollabuk-do Institute of Health and Environment, Imsil 55928, Korea; ${ }^{2}$ Division of Microbiology, Jeollanam-do Institute of Health and \\ Environment, Muan 58568, Korea
}

\begin{abstract}
To grasp the infection status of Metagonimus spp. metacercariae (MsMc), the freshwater fishes were surveyed from Seomjin-gang (river) and Tamjin-gang in the Republic of Korea. Total 1,604 fishes from 7 local sites of Seomjin-gang and 1,649 fishes from 2 sites of Tamjin-gang were examined for 6 years (2012-2017) by the artificial digestion method. MsMc were detected in fishes from 7 sites, i.e., Osucheon in Imsil-gun (36.3\% fish in 6 spp.), Seomjin-gang in Sunchanggun (49.8\% in 18 spp.), Songdaecheon in Namwon-si (64.5\% in 8 spp.), Seomjin-gang in Gokseong-gun (72.4\% in 14 spp.) and in Gurye-gun (78.8\% in 17 spp.), Hoengcheon (75.9\% in 11 spp.) and Namsancheon (58.9\% in 7 spp.) in Hadong-gun. Their average densities were 4.2, 86.8, 39.9, 43.1, 246.5, 173.6 and 67.5 per fish infected respectively. Prevalence with MsMc in rasborinid fish from Seomjin-gang was $89.2 \%$ and their intensity was 73.6 per fish infected. Endemicities of MsMc in rasborinid fish from Seomjin-gang were significantly higher in fishes from the lower reaches (prevalence: $98.7 \%$; density: 137$)$ rather than in fishes from the middle $(93.5 \%$; 38$)$ and upper $(72.4 \%$; 13$)$ reaches. MsMc were also detected in $56.1 \%$ and $66.4 \%$ fishes from 2 surveyed areas, i.e., the middle reaches in Jangheung-gun and the lower reaches in Gangjin-gun, of Tamjin-gang, and their densities were 147 and 121 per fish infected. In susceptible fishes from Tamjin-gang, the prevalence was $84.1 \%$ and density was 227 per fish infected. By the present study, it was confirmed that MsMc is highly prevalent in the fishes from Seomjin-gang and Tamjin-gang in Korea.
\end{abstract}

Key words: Metagonimus spp., metacercaria, Seomjin-gang, Tamjin-gang

\section{INTRODUCTION}

Members in the genus Metagonimus Katsurada, 1912 (Digenea: Heterophyidae) are comprised more than 7 nominal species, i.e., M. yokogawai Katsurada, 1912, M. takahashii Suzuki, 1930, M. minutus Katsuta, 1932, M. katsuradai Izumi, 1935, M. otsurui Saito and Shimizu, 1968, M. miyatai Saito et al., 1997 and M. hakubensis Shimazu, 1999. Among 7 Metagonimus species, 3 ones, i.e., M. yokogawai, M. takahashii, and M. miyatai, are known to distribute in the Republic of Korea (Korea) [1,2]. Human infection by these species of fluke, metagonimiasis, is an important endemic disease together with clonorchiasis in

\footnotetext{
- Received 12 May 2018, revised 3 July 2018, accepted 29 July 2018.

*Corresponding author (wmsohn@gnu.ac.kr)

(C) 2018, Korean Society for Parasitology and Tropical Medicine

This is an Open Access article distributed under the terms of the Creative Commons Attribution Non-Commercial License (http://creativecommons.org/licenses/by-nc/4.0) which permits unrestricted non-commercial use, distribution, and reproduction in any medium, provided the original work is properly cited.
}

Korea [1-3]. Infections by M. yokogawai are chiefly prevalent in the riverside areas of eastern and southern coast of Korean peninsula [3-7]. Human cases by M. takahashii were first reported in inhabitants of Eumseong-gun (gun=county), Chungcheongnam-do (do=Province), along the upper reaches of the Namhan-gang [6]. Endemic areas of M. miyatai were confirmed among peoples residing around lakes and along the rivers and/or streams in inland of Korea [9-11]. These Metagonimus species give rise to severe gastrointestinal troubles and chronic diarrhea in heavily infected cases $[1,2,12]$.

As the infection sources of metagonimiasis, lots of fish species have been reported in Korea [13]. The sweet smelt (Plecoglossus altivelis), the sea rundace (Tribolodon hakonensis) and the Japanese seabass (Lateolabrax japonicus), are known to be the second intermediate hosts of M. yokogawai [13-16]. The crusian carp (Carassius auratus), common carp (Cyprinus carpio), sea rundace, and Japanese seabass are reported as the second intermediate hosts of $M$. takahashii $[13,16,17]$. As the second 
intermediate hosts of M. miyatai, many species of fish, including the sea rundace, pale chub, (Zacco platypus) and dark chub (Z. temminckii), are listed in Korea $[13,16,18]$.

On the other hand, many Korean workers have been investigated the infection status with zoonotic trematodes (ZT), i.e., $C$. sinensis, Metagonimus spp. including M. yokogawai, Centrocestus armatus and Echinostoma spp., metacercariae in fishes from various endemic areas to estimate the endemicities of these trematode infections [1,13]. In case of Metagonimus spp., most of studies were performed on the infection status of M. yokogawai in sweet smelts from the specific regions [19-25]. Recently, Cho et al. [26] surveyed on the infection status of ZT metacercariae including Metagonimus spp. in freshwater fish from Gangwondo, Korea. Sohn et al. [27] investigated the infection status of digenetic trematode metacercariae in freshwater fish from the water systems of Hantan-gang and Imjin-gang located in relatively northern regions of Korea. Sohn et al. [28] and Yoon et al. [29] reported the infection status with C. sinensis metacercariae in fishes from Seomjin-gang and Tamjin-gang. However, the infection status with MsMc in fish from Seomjin-gang and Tamjin-gang has not been widely and systematically examined yet, although these 2 riverside areas has been known as the endemic areas of heterophyid flukes including M. yokogawai [3,4,30-32]. Therefore, we performed the present study to know the infection status with MsMc in fishes from 2 rivers, Seomjingang and Tamjin-gang, located in the southern parts of Korea.

\section{MATERIALS AND METHODS}

\section{Collection sites of fish}

We collected total 1,604 freshwater fishes in 7 local sites of Seomjin-gang, i.e., Osucheon ("cheon" means stream) (Latitude: 35.528473; Longitude: 127.328177) in Imsil-gun, Seomjin-gang $(35.409674 ; 127.219528)$ in Sunchang-gun, Songdaecheon $(35.352539 ; 127.189819)$ in Namwon-si, Jeollabukdo, Seomjin-gang $(35.212588 ; 127.371886)$ in Gokseong-gun, Seomjin-gang $(35.200735 ; 127.491839)$ in Gurye-gun, Jeollanam-do, Hoengcheon $(35.107203 ; 127.807894)$ and Namsancheon $(35.095020 ; 127.798093)$ in Hadong-gun, Gyeongsangnam-do, for 5 years (2012-2016) (Fig. in [28]). We also collected total 1,132 fishes (22 species) in the middle reaches of Tamjin-gang in Jangheung-gun (Latitude: 34.425719; Longitude: 126. 543227) for 4 years (2014-2017) and total 517 fishes (17 species) in the lower reaches of Tamjin-gang in Gangin-gun (Latitude: 34. 380531; Longitude: 126. 485115),
Jeollanam-do, Korea in 2104 and 2017.

\section{Fishes examined in the upper reaches of Seomjin-gang}

Total 236 freshwater fish (11 species) from Osucheon in Imsil-gun, Jeollabuk-do were examined in 2012 and 2013. Fish species (No. of fish) examined were Squalidus japonicus coreanus (20), Microphysogobio jeoni (6), Pseudogobio esocinus (5), Carassius auratus (3), and Hemibarbus longirostris (1) including 6 ones with MsMc in Table 1. Total 310 freshwater fish $(29$ species) from Seomjin-gang in Sunchang-gun, Jeollabuk-do were examined in 2014 and 2015. Fish species (No. of fish) examined were Coreoperca herzi (19), Acheilognathus koreensis (12), Odontobutis platycephala (9), Coreoleuciscus splendidus (4), Acheilognathus yamatsutae (3), Abbottina springeri (3), Cobitis tetralin-

Table 1. Infection status of Metagonimus spp. metacercariae in freshwater fish from the upper reaches of Seomjin-gang (River)

\begin{tabular}{|c|c|c|c|c|}
\hline \multirow{2}{*}{ Locality and fish sp. } & \multirow{2}{*}{$\begin{array}{l}\text { No. of } \\
\text { fish } \\
\text { examined }\end{array}$} & \multirow{2}{*}{$\begin{array}{c}\text { No. (\%) } \\
\text { of fish } \\
\text { infected }\end{array}$} & \multicolumn{2}{|c|}{$\begin{array}{l}\text { No. of MsMc } \\
\text { detected }\end{array}$} \\
\hline & & & Range & Average \\
\hline \multicolumn{5}{|l|}{ Osucheon in Imsil-gun } \\
\hline Zacco platypus & 80 & $48(60.0)$ & $1-32$ & 4.2 \\
\hline Hemibarbus labeo & 56 & $1(1.8)$ & - & 1.0 \\
\hline Squalidus chankaensis & 35 & $8(22.9)$ & $1-10$ & 3.3 \\
\hline Opsariichthys uncirostris & 21 & $13(61.9)$ & $1-25$ & 5.1 \\
\hline Acanthorhodeus gracilis & 6 & $1(16.7)$ & - & 3.0 \\
\hline Rhodeus ocellatus & 3 & $2(66.7)$ & $2-4$ & 3.0 \\
\hline Subtotal & 201 & $73(36.3)$ & $1-32$ & 4.2 \\
\hline \multicolumn{5}{|c|}{ Seomjin-gang in Sunchang-gun } \\
\hline Pungtungia herzi & 56 & $13(23.2)$ & $1-9$ & 1.9 \\
\hline Zacco platypus & 51 & $45(88.2)$ & $1-200$ & 25.8 \\
\hline Pseudogobio esocinus & 32 & $13(40.6)$ & $1-60$ & 6.9 \\
\hline Zacco koreanus & 15 & $11(73.3)$ & $1-36$ & 7.9 \\
\hline Opsariichthys uncirostris & 14 & $14(100)$ & $1-45$ & 9.9 \\
\hline Carassius auratus & 14 & $1(7.1)$ & - & 5.0 \\
\hline $\begin{array}{l}\text { Sarcocheilichthys } \\
\text { variegatus }\end{array}$ & 12 & $4(33.3)$ & $1-6$ & 2.8 \\
\hline $\begin{array}{l}\text { Squalidus japonicus } \\
\text { coreanus }\end{array}$ & 11 & $3(27.3)$ & - & 1.0 \\
\hline $\begin{array}{l}\text { Acheilognathus } \\
\text { rhombeus }\end{array}$ & 10 & $3(30.0)$ & $1-4$ & 2.3 \\
\hline Siniperca scherzeri & 10 & $1(10.0)$ & - & 2.0 \\
\hline $\begin{array}{l}\text { Squalidus gracilis } \\
\text { majimae }\end{array}$ & 6 & $1(16.7)$ & - & 1.0 \\
\hline Acanthorhodeus gracilis & 6 & $5(83.3)$ & $7-40$ & 16.2 \\
\hline Gnathopogon strigatus & 5 & $4(80.0)$ & $5-14$ & 7.5 \\
\hline Hemibarbus longirostris & 5 & $4(80.0)$ & $2-14$ & 8.0 \\
\hline Hemibarbus labeo & 4 & $1(25.0)$ & - & 2.0 \\
\hline Plecoglossus altivelis & 3 & $3(100)$ & $282-6,750$ & 3,146 \\
\hline Cyprinus carpio & 2 & $1(50.0)$ & - & 1.0 \\
\hline Hemiculter leucisculus & 1 & $1(100)$ & - & 1.0 \\
\hline Subtotal & 257 & $128(49.8)$ & $1-6,750$ & 86.8 \\
\hline Total & 458 & $201(43.9)$ & $1-6,750$ & 56.8 \\
\hline
\end{tabular}


eata (2), Acheilognathus lanceolatus (1), Acanthorhodeus macropterus (1), Cobitis lutheri (1), and Misgurnus anguillicaudatus (1) including 18 ones with MsMc in Table 1.

\section{Fishes examined in the middle reaches of Seomjingang}

Total 196 freshwater fish (14 species) from Songdaecheon in Namwon-si, Jeollabuk-do were examined in 2012 and 2013. Fish species (No. of fish) examined were C. herzi (6), Pseudorasbora parva (2), A. springeri (2), P. esocinus (1), Iksookimia longicorpus (1), and Lepomis macrochirus (1) including 8 ones with MsMc in Table 2. Total 289 freshwater fish (15 species) from Seomjin-gang

Table 2. Infection status of Metagonimus spp. metacercariae in freshwater fish from the middle reaches of Seomjin-gang (River)

\begin{tabular}{|c|c|c|c|c|}
\hline \multirow{2}{*}{ Locality and fish sp. } & \multirow{2}{*}{$\begin{array}{c}\text { No. of } \\
\text { fish } \\
\text { examined }\end{array}$} & \multirow{2}{*}{$\begin{array}{l}\text { No. (\%) } \\
\text { of fish } \\
\text { infected }\end{array}$} & \multicolumn{2}{|c|}{ No. of MsMc detected } \\
\hline & & & Range & Average \\
\hline \multicolumn{5}{|c|}{ Songdaecheon in Namwon-si } \\
\hline Zacco koreanus & 57 & $56(98.3)$ & $2-334$ & 60.5 \\
\hline Pungtungia herzi & 47 & $10(21.3)$ & $1-4$ & 2.0 \\
\hline Zacco platypus & 46 & 45 (97.8) & $1-175$ & 28.4 \\
\hline $\begin{array}{c}\text { Rhynchocypris } \\
\text { oxycephalus }\end{array}$ & 21 & $1(4.8)$ & - & 1.0 \\
\hline $\begin{array}{l}\text { Microphysogobio } \\
\text { koeensis }\end{array}$ & 5 & $1(20.0)$ & - & 4.0 \\
\hline Carassius auratus & 3 & $1(33.3)$ & - & 1.0 \\
\hline Gnathopogon strigatus & 2 & $2(100)$ & $1-8$ & 4.5 \\
\hline $\begin{array}{l}\text { Squalidus gracilis } \\
\text { majimae }\end{array}$ & 2 & $2(100)$ & - & 1.0 \\
\hline Subtotal & 183 & $118(64.5)$ & $1-334$ & 39.9 \\
\hline \multicolumn{5}{|c|}{ Seomjin-gang in Gokseong-gun } \\
\hline Zacco koreanus & 52 & $41(78.9)$ & $1-124$ & 18.0 \\
\hline Zacco platypus & 43 & $43(100)$ & $1-130$ & 23.4 \\
\hline $\begin{array}{l}\text { Coreoleuciscus } \\
\text { splendidus }\end{array}$ & 37 & $15(40.5)$ & $1-6$ & 1.9 \\
\hline $\begin{array}{l}\text { Sarcocheilichthys } \\
\text { variegatus }\end{array}$ & 31 & $21(67.7)$ & $1-15$ & 3.8 \\
\hline $\begin{array}{l}\text { Squalidus japonicus } \\
\text { coreanus }\end{array}$ & 27 & $22(81.5)$ & $1-10$ & 2.7 \\
\hline Pungtungia herzi & 22 & $13(59.1)$ & $1-5$ & 2.3 \\
\hline $\begin{array}{l}\text { Hemibarbus } \\
\text { longirostris }\end{array}$ & 20 & 19 (95.5) & $1-33$ & 12.0 \\
\hline $\begin{array}{l}\text { Microphysogobio } \\
\text { koeensis }\end{array}$ & 16 & $8(50.0)$ & $1-4$ & 2.4 \\
\hline Pseudogobio esocinus & 16 & $13(81.3)$ & $1-65$ & 12.9 \\
\hline Coreoperca herzi & 11 & $2(18.2)$ & $2-5$ & 3.5 \\
\hline $\begin{array}{l}\text { Acheilognathus } \\
\text { majusculus }\end{array}$ & 5 & $4(80.0)$ & $3-9$ & 5.0 \\
\hline Plecoglossus altivelis & 2 & $2(100)$ & $1,370-4,380$ & 2,875 \\
\hline Hemibarbus labeo & 2 & $2(100)$ & $2-9$ & 5.5 \\
\hline $\begin{array}{l}\text { Opsariichthys } \\
\text { amurensis }\end{array}$ & 2 & $2(100)$ & $11-762$ & 386.5 \\
\hline Subtotal & 286 & $207(72.4)$ & $1-4,380$ & 43.1 \\
\hline Total & 469 & $325(69.3)$ & $1-4,380$ & 41.9 \\
\hline
\end{tabular}

in Gokseong-gun, Jeollanam-do were examined in 2015 and 2016. Fish species (No. of fish) examined were Ladislabia taczanowskii (1) including 14 ones with MsMc in Table 2.

\section{Fishes examined in the lower reaches of Seomjin-gang}

Total 183 freshwater fish (21 species) from Seomjin-gang in Gurye-gun, Jeollanam-do were examined in 2014. Fish species (No. of fish) examined were C. auratus (5), O. platycephala (4), A. lanceolatus (3), and S. scherzeri (1) including 17 ones with MsMc in Table 3. Total 156 freshwater fish (13 species) from Hoengcheon in Hadong-gun, Gyeongsangnam-do were examined in 2014 and 2016. Fish species (No. of fish) examined were C. auratus (1) and O. platycephala (1) including 11 ones with MsMc in Table 3. Total 234 freshwater fish (12 species) from Namsancheon in Hadong-gun, Gyeongsangnam-do were examined in 2015 and 2016. Fish species (No. of fish) examined were C. auratus (16), A. koreensis (7), A. gracilis (2), C. splendidus (1), and $O$. platycephala (1) including 7 ones with MsMc in Table 3.

\section{Fishes examined in Tamjin-gang}

In the middle reaches in Jangheung-gun, total 1,132 fishes in 22 species were examined for 4 years (2014-2017). Fish species (No. of fish) examined were Micropterus salmoides (8), A. koreensis (7), and Cyprinus carpio (2) including 19 ones with MsMc in Table 5. In the lower reaches in Gangiin-gun, a total of 517 fishes in 17 species were examined in 2014 and 2017. Fish species (No. of fish) examined were A. lanceolatus (22), C. herzi (3), and Mugil cephalus (1) including 14 ones with MsMc in Table 5.

\section{Examination methods}

All collected fishes with ice were transferred to the laboratory of the Department of Parasitology and Tropical Medicine, Gyeongsang National University College of Medicine, Jinju, Korea. After the identification of fish species, they were individually ground with a mortar or grinder. Each ground fish meat was mixed with artificial gastric juice and the mixture was incubated at $36^{\circ} \mathrm{C}$ for $2 \mathrm{hr}$. The digested material was filtered with $1 \times 1 \mathrm{~mm}$ of mesh, and washed with $0.85 \%$ saline untill the supernatant is clear. The sediment was carefully examined under a stereomicroscope. The metacercariae of Metagonimus spp. (MsMc) were separately collected by the general feature [13], and they were counted to get hold of infection rates (\%) and densities (No. of MsMc per fish infected) by fish species. 
Table 3. Infection status of Metagonimus spp. metacercariae in freshwater fish from the lower reaches of Seominin-gang (River)

\begin{tabular}{|c|c|c|c|c|}
\hline \multirow{2}{*}{ Locality and fish sp. } & \multirow{2}{*}{$\begin{array}{c}\text { No. of } \\
\text { fish } \\
\text { examined }\end{array}$} & \multirow{2}{*}{$\begin{array}{c}\text { No. (\%) } \\
\text { of fish } \\
\text { infected }\end{array}$} & \multicolumn{2}{|c|}{ No. of MsMc detected } \\
\hline & & & Range & Average \\
\hline \multicolumn{5}{|l|}{ Seomjin-gang in Gurye-gun } \\
\hline Zacco platypus & 24 & $24(100)$ & $6-520$ & 126.3 \\
\hline Pungtungia herzi & 21 & $14(66.7)$ & $1-8$ & 2.6 \\
\hline $\begin{array}{l}\text { Squalidus japonicus } \\
\text { coreanus }\end{array}$ & 15 & $12(80.0)$ & $1-10$ & 3.7 \\
\hline Zacco koreanus & 14 & $11(78.6)$ & $3-290$ & 64.0 \\
\hline $\begin{array}{l}\text { Sarcocheilichthys } \\
\text { nigripinnis }\end{array}$ & 14 & $13(92.9)$ & $1-52$ & 13.6 \\
\hline $\begin{array}{l}\text { Opsariichthys } \\
\text { uncirostris }\end{array}$ & 13 & $13(100)$ & $52-495$ & 143.8 \\
\hline $\begin{array}{l}\text { Acheilognathus } \\
\text { rhombeus }\end{array}$ & 11 & $10(90.9)$ & $17-150$ & 54.0 \\
\hline Coreoperca herzi & 10 & $4(40.0)$ & $1-3$ & 1.8 \\
\hline Hemibarbus labeo & 10 & $3(30.0)$ & - & 1.0 \\
\hline $\begin{array}{l}\text { Squalidus gracilis } \\
\text { majimae }\end{array}$ & 8 & $5(62.5)$ & $1-2$ & 1.4 \\
\hline Pseudogobio esocinus & 7 & $7(100)$ & $6-62$ & 28.1 \\
\hline $\begin{array}{l}\text { Microphysogobio } \\
\text { koeensis }\end{array}$ & 6 & $6(100)$ & $2-22$ & 6.2 \\
\hline $\begin{array}{l}\text { Acanthorhodeus } \\
\text { gracilis }\end{array}$ & 5 & $4(80.0)$ & $10-58$ & 37.5 \\
\hline Abbottina rivularis & 5 & $1(20.0)$ & - & 2.0 \\
\hline Plecoglossus altivelis & 3 & $3(100)$ & $6,280-10,750$ & 8,727 \\
\hline Pseudorasbora parva & 3 & $3(100)$ & $4-31$ & 15.7 \\
\hline Hemibarbus longirostris & 1 & $1(100)$ & - & 3.0 \\
\hline Subtotal & 170 & $134(78.8)$ & $1-10,750$ & 246.5 \\
\hline \multicolumn{5}{|c|}{ Hoengcheon in Hadong-gun } \\
\hline Zacco koreanus & 35 & $35(100)$ & $1-5,860$ & 369.2 \\
\hline Zacco platypus & 27 & $27(100)$ & $2-1,510$ & 115.3 \\
\hline $\begin{array}{l}\text { Acheilognathus } \\
\text { koreensis }\end{array}$ & 20 & $1(5.0)$ & - & 1.0 \\
\hline Pungtungia herzi & 16 & $7(43.8)$ & $1-3$ & 2.1 \\
\hline Coreoperca herzi & 11 & $5(45.5)$ & $1-2$ & 1.4 \\
\hline Zacco temminckii & 10 & $10(100)$ & $6-480$ & 156.5 \\
\hline Hemibarbus longirostris & 8 & $8(100)$ & $2-145$ & 63.0 \\
\hline $\begin{array}{l}\text { Pseudogobio } \\
\text { esocinus }\end{array}$ & 7 & $6(85.7)$ & $4-16$ & 8.5 \\
\hline Abbottina springeri & 7 & $4(57.1)$ & $3-358$ & 97.8 \\
\hline $\begin{array}{l}\text { Coreoleuciscus } \\
\text { splendidus }\end{array}$ & 4 & $3(75.0)$ & - & 1.0 \\
\hline $\begin{array}{l}\text { Squalidus gracilis } \\
\text { majimae }\end{array}$ & 1 & $1(100)$ & - & 1.0 \\
\hline Subtotal & 146 & $107(73.3)$ & $1-5,860$ & 173.6 \\
\hline \multicolumn{5}{|c|}{ Namsancheon in Hadong-gun } \\
\hline Zacco koreanus & 57 & $57(100)$ & $1-2,860$ & 104.3 \\
\hline Pseudogobio esocinus & 46 & $4(8.7)$ & $1-2$ & 1.3 \\
\hline Zacco platypus & 41 & $41(100)$ & 3-101 & 27.4 \\
\hline Pungtungia herzi & 35 & $7(20.0)$ & $1-7$ & 2.3 \\
\hline Hemibarbus longirostris & 14 & $1(7.1)$ & - & 1.0 \\
\hline Zacco temminckii & 11 & $11(100)$ & $2-580$ & 104.5 \\
\hline $\begin{array}{l}\text { Squalidus gracilis } \\
\text { majimae }\end{array}$ & 3 & $1(33.3)$ & - & 1.0 \\
\hline Subtotal & 207 & $122(58.9)$ & $1-2,860$ & 67.5 \\
\hline Total & 523 & $363(69.4)$ & $1-10,750$ & 165 \\
\hline
\end{tabular}

\section{RESULTS}

\section{Infection status with MsMc in the upper reaches of Seomjin-gang}

The metacercariae of Metagonimus spp. (MsMc) were detected in 201 (43.9\%) out of 458 fishes in 20 species from the upper reaches of Seomjin-gang, i.e., Osucheon in Imsil-gun and Seomjin-gang in Sunchang-gun, Jeollabuk-do, and their average density was 56.8 per fish infected. The infection status by the fish species and surveyed areas was detailedly shown in Table 1.

\section{Infection status with MsMc in the middle reaches of Seomjin-gang}

MsMc were detected in 325 (69.3\%) out of 469 fishes in 18 species from the middle reaches of Seomjin-gang, i.e., Songdaecheon in Namwon-si, Jeollabuk-do and Seomjin-gang in Gokseong-gun, Jeollanam-do, and their average density was 41.9 per fish infected. The infection status by the fish species and surveyed areas was detailedly revealed in Table 2.

\section{Infection status with MsMc in the lower reaches of Seomjin-gang}

MsMc were detected in 363 (69.4\%) out of 523 fishes in 21 species from the lower reaches of Seomjin-gang, i.e., Seomjingang in Gurye-gun, Jeollanam-do, Hoengcheon and Namsancheon in Hadong-gun, Gyeongsangnam-do, and their average

Table 4. Infection status of Metagonimus spp. metacercariae in rasborinid fish from Seomjin-gang (River)

\begin{tabular}{|c|c|c|c|c|}
\hline \multirow[t]{2}{*}{ Locality and fish sp. } & \multirow{2}{*}{$\begin{array}{c}\text { No. of } \\
\text { fish } \\
\text { examined }\end{array}$} & \multirow{2}{*}{$\begin{array}{l}\text { No. (\%) } \\
\text { of fish } \\
\text { infected }\end{array}$} & \multicolumn{2}{|c|}{$\begin{array}{l}\text { No. of MsMc } \\
\text { detected }\end{array}$} \\
\hline & & & Range & Average \\
\hline \multicolumn{5}{|l|}{ Upper reaches } \\
\hline Zacco platypus & 131 & $93(71.0)$ & $1-200$ & 14.6 \\
\hline Zacco koreanus & 15 & $11(73.3)$ & $1-36$ & 7.9 \\
\hline Opsariichthys uncirostris & 35 & 27 (77.1) & $1-45$ & 7.6 \\
\hline Subtotal & 181 & $131(72.4)$ & $1-200$ & 12.6 \\
\hline \multicolumn{5}{|l|}{ Middle reaches } \\
\hline Zacco platypus & 89 & 88 (98.9) & $1-175$ & 26.0 \\
\hline Zacco koreanus & 109 & 97 (89.0) & $1-334$ & 42.5 \\
\hline Opsariichthys amurensis & 2 & $2(100)$ & $11-762$ & 386.5 \\
\hline Subtotal & 200 & $187(93.5)$ & $1-762$ & 38.4 \\
\hline \multicolumn{5}{|l|}{ Lower reaches } \\
\hline Zacco platypus & 92 & $92(100)$ & $2-1,510$ & 79.0 \\
\hline Zacco koreanus & 106 & $103(97.2)$ & $1-5,860$ & 190.0 \\
\hline Zacco temminckii & 21 & $21(100)$ & $2-580$ & 129.2 \\
\hline Opsariichthys amurensis & 13 & $13(100)$ & $52-495$ & 143.8 \\
\hline Subtotal & 232 & $229(98.7)$ & $1-5,860$ & 137.2 \\
\hline Total & 613 & $547(89.2)$ & $1-5,860$ & 73.6 \\
\hline
\end{tabular}


density was 165 per fish infected. The infection status by the fish species and surveyed areas was detailedly shown in Table 3.

\section{Infection status with MsMc in rasborinid fish from Seomjin-gang}

MsMc were detected in 547 (89.2\%) out of total 613 rasborinid fishes from Seomjin-gang, and their average density was

Table 5. Infection status of Metagonimus spp. metacercariae in fishes from Tamjin-gang (River) in Jeollanam-do, Korea

\begin{tabular}{|c|c|c|c|c|}
\hline \multirow[t]{2}{*}{ Locality and fish sp. } & \multirow{2}{*}{$\begin{array}{c}\text { No. of } \\
\text { fish } \\
\text { examined }\end{array}$} & \multirow{2}{*}{$\begin{array}{l}\text { No. (\%) } \\
\text { of fish } \\
\text { infected }\end{array}$} & \multicolumn{2}{|c|}{$\begin{array}{l}\text { No. of MsMc } \\
\text { detected }\end{array}$} \\
\hline & & & Range & Average \\
\hline \multicolumn{5}{|c|}{ Middle reaches in Jangheung-gun } \\
\hline Zacco temminckii & 152 & $143(94.1)$ & $1-2,460$ & 65.2 \\
\hline Pungtungia herzi & 152 & $51(33.6)$ & $1-20$ & 2.4 \\
\hline Zacco platypus & 138 & $110(79.7)$ & $1-140$ & 16.3 \\
\hline Carassius auratus & 116 & $63(54.3)$ & $1-924$ & 126.6 \\
\hline Pseudogobio esocinus & 86 & $70(81.4)$ & $1-86$ & 12.0 \\
\hline Coreoperca kawamebari & 84 & $31(36.9)$ & $1-61$ & 13.9 \\
\hline Hemibarbus longirostris & 77 & 49 (63.6) & $1-45$ & 7.3 \\
\hline $\begin{array}{l}\text { Sarcocheilichthys } \\
\text { variegatus }\end{array}$ & 54 & $17(31.5)$ & $1-7$ & 2.0 \\
\hline Plecoglossus altivelis & 52 & $51(98.1)$ & $1-5,320$ & 1,339 \\
\hline Acheilognathus lanceolatus & 52 & $1(1.9)$ & - & 2.0 \\
\hline Odontobutis platycephala & 48 & $7(14.6)$ & $1-8$ & 3.1 \\
\hline $\begin{array}{l}\text { Sarcocheilichthys } \\
\text { nigripinnis }\end{array}$ & 29 & $6(13.3)$ & $1-32$ & 8.3 \\
\hline Acheilognathus yamatsutae & 23 & $2(8.7)$ & $4-5$ & 4.5 \\
\hline Coreoperca herzi & 16 & $3(18.8)$ & - & 1.0 \\
\hline Acanthorhodeus gracilis & 11 & $10(90.9)$ & $1-55$ & 31.9 \\
\hline Acheilognathus rhombeus & 10 & $6(60.0)$ & $1-1,400$ & 417.7 \\
\hline Siniperca scherzeri & 6 & $1(16.7)$ & - & 1.0 \\
\hline Hemiculter eigenmanni & 6 & $2(33.3)$ & - & 4.0 \\
\hline Squalidus gracilis majimae & 3 & $3(100)$ & $1-5$ & 2.7 \\
\hline Subtotal & 1,115 & $626(56.1)$ & $1-5,320$ & 147 \\
\hline \multicolumn{5}{|c|}{ Lower reaches in Gangjin-gun } \\
\hline Zacco platypus & 75 & 70 (93.3) & $1-58$ & 8.1 \\
\hline Pungtungia herzi & 70 & $23(32.9)$ & $1-8$ & 2.4 \\
\hline Carassius auratus & 62 & $54(87.1)$ & $1-780$ & 38.1 \\
\hline Pseudogobio esocinus & 51 & $41(80.4)$ & $1-20$ & 5.4 \\
\hline Plecoglossus altivelis & 40 & $40(100)$ & $26-4,280$ & 841 \\
\hline Sarcocheilichthys nigripinis & 33 & $14(42.4)$ & $1-17$ & 3.2 \\
\hline $\begin{array}{l}\text { Acanthorhodeus } \\
\text { macropterus }\end{array}$ & 28 & $12(42.9)$ & $1-10$ & 3.2 \\
\hline Zacco temminckii & 26 & 25 (96.2) & $1-875$ & 110.3 \\
\hline Odontobutis platycephala & 26 & $5(19.2)$ & $1-6$ & 2.8 \\
\hline Coreoperca kawamebari & 25 & $9(36.0)$ & $1-5$ & 1.9 \\
\hline Hemibarbus longirostris & 24 & 19 (79.2) & $1-15$ & 4.9 \\
\hline $\begin{array}{l}\text { Sarcocheilichthys } \\
\text { variegatus }\end{array}$ & 20 & $3(15.0)$ & $2-4$ & 3.0 \\
\hline Acheilognathus rhombeus & 9 & $9(100)$ & $2-67$ & 25.8 \\
\hline Lateolabrax japonicus & 2 & $2(100)$ & $1-4$ & 2.5 \\
\hline Subtotal & 491 & $326(66.4)$ & $1-4,280$ & 121 \\
\hline Total & 1,606 & 952 (59.3) & $1-5,320$ & 138 \\
\hline
\end{tabular}

73.6 per fish infected. The infection status by the rasborinid fish species and surveyed reaches of river was detailedly revealed in Table 4.

\section{Infection status with MsMc in fishes from Tamjin-gang}

MsMc were detected in 626 (56.1\%) out of 1,115 fishes in positive fish species from the middle reaches in Jangheung-gun and their average density was $147 \mathrm{per}$ fish infected. MsMc were found in 326 (66.4\%) out of 491 fishes in positive fish species from the lower reaches in Gangiin-gun and their average density was 121 per fish infected. The infection status by the fish species and surveyed areas was detailedly revealed in Table 5.

\section{Infection status with MsMc in the susceptible fish species from Tamjin-gang}

MsMc were detected in 556 (84.1\%) out of total 661 susceptible fishes from Tamjin-gang, and their average density was 227 per fish infected. The infection status by the fish species and surveyed areas was detailedly revealed in Table 6 .

\section{DISCUSSION}

By the present study, it was confirmed that MsMc are more or less prevalent in fishes from Seomjin-gang and Tamjingang. The positive rates with MsMc were very similar, 55.4\% and 59.3\%, in fishes from 2 rivers, but average metacercarial densities were 96 and 138 per fish infected, higher in fishes from Tamjin-gang. We couldn't compare the endemicity of

Table 6. Infection status of Metagonimus spp. metacercariae in susceptible fishes from Tamin-gang (River) in Jeollanam-do, Korea

\begin{tabular}{|c|c|c|c|c|}
\hline \multirow[t]{2}{*}{ Locality and fish sp. } & \multirow{2}{*}{$\begin{array}{l}\text { No. of fish } \\
\text { examined }\end{array}$} & \multirow{2}{*}{$\begin{array}{l}\text { No. (\%) } \\
\text { of fish } \\
\text { infected }\end{array}$} & \multicolumn{2}{|c|}{$\begin{array}{c}\text { No. of MsMc } \\
\text { detected }\end{array}$} \\
\hline & & & Range & Average \\
\hline \multicolumn{5}{|c|}{ Tamjin-gang in Jangheung-gun } \\
\hline Zacco platypus & 138 & $110(79.7)$ & $1-140$ & 16.3 \\
\hline Zacco temminckii & 152 & $143(94.1)$ & $1-2,460$ & 65.2 \\
\hline Carassius auratus & 116 & $63(54.3)$ & $1-924$ & 126.6 \\
\hline Plecoglossus altivelis & 52 & $51(98.1)$ & $1-5,320$ & 1,339 \\
\hline Subtotal & 458 & $367(80.1)$ & $1-5,320$ & 238 \\
\hline \multicolumn{5}{|c|}{ Tamjin-gang in Gangjin-gun } \\
\hline Zacco platypus & 75 & 70 (93.3) & $1-58$ & 8.1 \\
\hline Zacco temminckii & 26 & $25(96.2)$ & $1-875$ & 110.3 \\
\hline Carassius auratus & 62 & $54(87.1)$ & $1-780$ & 38.1 \\
\hline Plecoglossus altivelis & 40 & $40(100)$ & $26-4,280$ & 841 \\
\hline Subtotal & 203 & $189(93.1)$ & $1-4,280$ & 205 \\
\hline Total & 661 & $556(84.1)$ & $1-5,320$ & 227 \\
\hline
\end{tabular}


Table 7. Comparison of the infection status ${ }^{a}$ with Metagonimus spp. metacercariae in fishes from Seomjin-gang and Tamjin-gang

\begin{tabular}{lcrr}
\hline \multirow{2}{*}{ Items } & \multicolumn{3}{c}{ Infection status of MsMc in fishes from } \\
\cline { 2 - 4 } & Seomjin-gang & Tamjin-gang & Total \\
\hline No. (\%) of fish examined & $1,604(49.3)$ & $1,649(50.7)$ & $3,253(100)$ \\
Overall positive rate (\%) & $889 / 1,604(55.4)$ & $952 / 1,649(57.7)$ & $1,841 / 3,253(56.6)$ \\
Total metacercarial density & 95.5 & 138.1 & 117.5 \\
No. (\%) of rasborinids examined & $613(38.2)$ & $391(23.7)$ & $1,004(30.9)$ \\
No. (\%) of rasborinids infected & $547(89.2)$ & $348(89.0)$ & $895(89.1)$ \\
MsMc density in rasborinids & 73.6 & 41.5 & 61.1 \\
\hline
\end{tabular}

aPositive rate: No. of fish infected/No. of fish examined x100; metacercarial density: mean No. of MsMc per fish infected.

${ }^{b}$ No. of rasborinid fish/Total No. of fish examined $\times 100$.

MsMc in the most susceptible fish species, sweet smelt (P. altivelis), so the number of fish examined (8 from Seomjin-gang and 92 from Tamjin-gang) was too much different in 2 rivers. However, their prevalences were $100 \%$ and $98.9 \%$ and densities were 5,171 and 1,120 per fish infected in sweet smelts from Seomjin-gang and Tamjin-gang each. In another MsMc susceptible fish group, rasborinid fish such as Zacco spp. and $O$. uncirostris amurensis, the prevalences were very similar, $89.2 \%$ and $89.0 \%$, in 2 rivers, but average metacercarial densities were 74 and 42 per fish infected, more or less higher in Seomjingang (Table 7). On the other hand, in the rasborinid fish from Seomjin-gang, the prevalences were $72.4 \%$ (the upper reaches), $93.5 \%$ (the middle reaches), and $98.7 \%$ (the lower reaches), and metacercarial densities were 12.6, 38.4, and 137.2 per fish infected respectively. These findings suggested that the endemicity with MsMc is more higher in fish from the lower reaches than in fish from the upper and middle reaches of Seomjin-gang. In the susceptible fish species, i.e., Zacco spp., C. auratus and $P$. altivelis, from Tamjin-gang, the prevalence was $84.1 \%$ (80.1\% in the middle reaches and $93.1 \%$ in the lower reaches) and MsMc density was 227 (238 in the middle reaches and 205 in the lower reaches) per fish infected. Therefore, the endemicity with MsMc is similar in fish from 2 surveyed sites of Tamjin-gang.

With regard to the infection status of MsMc in sweet smelts, $P$. altivelis, from Seomjin-gang and Tamjin-gang, at least 4 studies were available $[4,21,22,25]$. In 1977, Chai et al. [4] reported $100 \%$ prevalence and 15,688 MsMc per fish in 20 sweet smelts from a water reservoir nearby Tamjin-gang in Jangheung-gun. Seo et al. [22] detected av. 14,887 MsMc in all 16 sweet smelts from Tamjin-gang in Gangjin-gun. In 1985, Song et al. [21] reported 92.3\% prevalence and $636 \mathrm{MsMc}$ per fish in 12 sweet smelts from Tamjin-gang in Gangjin-gun. Cho et al. [25] detected av. 1,037 and 1,511 MsMc per fish in 16 sweet smelts from
Tamjin-gang in Gangiin-gun and in 20 ones from Seomjin-gang in Gurye-gun, Jeollanam-do. Song et al. [21] also reported 2,724 and 2,412 MsMc per fish in each 5 sweet smelts from Seomjingang in Gokseong-gun and Gurye-gun, Jeollanam-do. In this study, all 8 sweet smelts from Seomjin-gang were infected with av. 5,171 MsMc, and 91 (98.9\%) sweet smelts from Tamgingang were infected with 1,120 MsMc per fish infected. From the above findings of present and previous studies, we can suppose that the sweet smelts naturally produced in 2 rivers are highly infected with MsMc and the riverside areas are to be the highly endemic regions of metagonimiasis.

The rasborinid fish, i.e., Z. platypus, Z. koreanus, Z. temminckii and $O$. uncirostris amurensis, are known as the susceptible fish hosts of MsMc in both regions without and/or with sweet smelts in Korea. These fish species are also known as the second intermediate hosts of M. mixatai $[9,18]$. One of them, $Z$. platypus, is the most dominant species in the water systems of Korea. And then the rasborinid fish, especially Zacco spp., are highly recommended as the index fish of MsMc to evaluate the endemicity of metagonimiasis. In the present study, total 1004 (30.9\%) rasborinid fish (613 from Seomjin-gang: 38.2\% and 391 from Tamjin-gang: 23.7\%) were examined, and 895 (89.1\%) ones (547 in Seomjin-gang: $89.2 \%$ and 348 in Tamjin-gang: $89.0 \%$ ) were to be infected with MsMc. Their density was 61.1 per fish infected (73.6 in Seomjin-gang and 41.5 in Tamjin-gang) (Table 7). In the water systems of Gangwon-do, the prevalences with MsMc were $23.5-100 \%$ (85.2\% in average) in rasborinid fish and their densities were 3.4-108 (29.7 in average) in 10 surveyed areas [26]. Sohn et al. [27] reported $73.9 \%$ and $72.1 \% \mathrm{MsMc}$ prevalences in the rasborinid fish from the water systems of Hantan-gang and Imjin-gang. They also reported av. 43.1 and 18.6 MsMc densities in the rasborinid fish from 2 surveyed areas [27]. From the aforementioned findings, we can suppose that the endemicities with MsMc in 
fishes from Seomjin-gang and Tamjin-gang are more higher than those from the water systems of Gangwon-do, Hantangang and Imjin-gang.

Among fishes from Seomjin-gang, some rasborinid fishes, i.e., Z. koreanus and Z. temminckii from Hoengcheon and Namsancheon in Hadong-gun, O. uncirostris amurensis from Seomjin-gang in Gurye-gun and Z. platypus from Seomjin-gang in Gurye-gun and Hoengcheon in Hadong-gun, were revealed $100 \%$ prevalences and more than $100 \mathrm{MsMc}$ densities. In fishes from Tamjin-gang, crusian carp, C. auratus, from Jangheunggun and dark chub, Z. temminckii, from Gangjin-gun were highly and heavily infected with MsMc. Among fishes from the water systems of Gangwon-do, 90.0\% sea rundace, T. hakonensis, from Namdaecheon in Yangyang-gun and 97.4\% dark chub, Z. temminckii, from Joyang-gang in Jeongseon-gun were infected with 449 and $130 \mathrm{MsMc}$ per fish infected [26]. Sohn et al. [27] reported $92.3 \%$ and $100 \%$ prevalences and 132 and 102 MsMc densities in 26 P. esocinus and 22 Z. platypus from Hantan-gang in Cheorwon-gun, Gangwon-do. These findings on the high infection status with MsMc will be helpful to perform a study on the experimental metagonimiasis to be needed massive MsMc.

More than 7 valid species have been reported in the genus Metagonimus flukes in the literatures. All of them mainly distributed in Asian countries such as Japan, Korea, China and Taiwan [2]. At least 3 human infecting species, i.e., M. yokogawai, M. takahashii and M. miyatai, are known to exist commonly in Japan and Korea $[1,2]$. They are morphologically differentiated in adult stage by the locations of uterus and vitellaria, and the size of eggs, but not in metacercarial stages in the fish intermediate hosts. The cercariae of Metagonimus spp. naturally shed from freshwater snails, Semisulcospira coreana and S. liberti$n a$, which are known as the first intermediate hosts in Korea, and they penetrate into the second intermediate hosts. As the second intermediate hosts of Metagonimus spp., numerous species of fish have been reported in Korea. However, some fish species are known as hosts of specific Metagonimus species, i.e., P. altivelis, T. hakonensis and L. japonicus for M. yokogawai [13-16]; C. auratus, C. carpio, T. hakonensis and L. japonicus for M. takahashii $[13,16,17]$; Z. platypus and Z. temminckii for M. miyatai $[13,18]$. Does each species of Metagonimus spp. cercariae have the host-specificity? How does each species of cercariae encyst in the favorable fish hosts only in even highly endemic environment like Seomjin-gang and Tamjin-gang? Studies on the host-specificity of each Metagonimus sp. in fish hosts should be clarified in the near future through the morphological analysis of adult worms recovered from experimental animals, which are infected with MsMc from some susceptible species of fish, i.e., sweet smelt, sea rundace, crusian carp, pale chub and dark chub from a same endemic area.

Conclusively, by the present study, it was confirmed that MsMc are more prevalent in fishes from Seomjin-gang and Tamjin-gang than from any other rivers in Korea. Peoples residing in riverside areas of the 2 rivers should pay attention to the raw consumption of the susceptible fish hosts like chubs, Zacco spp., and crusian carp, $C$. auratus as well as sweet smelt, $P$. altivelis.

\section{ACKNOWLEDGMENTS}

This study was supported by an anti-communicable diseases control program, 2014E5400200 (Investigation of fish-borne parasites and acquisition of their biological resources in the southern regions of Korea) of National Institute of Health $(\mathrm{NIH})$, Korea Centers for Disease Control and Prevention (KCDCP). We thank Jung-A Kim and Hee-Joo Kim (Department of Parasitology and Tropical Medicine, Gyeongsang National University College of Medicine, Jinju, Korea), for their help in the examination of fish.

\section{CONFLICT OF INTEREST}

The authors have no conflicts of interest concerning the work reported in this paper.

\section{REFERENCES}

1. Chai JY, Lee SH. Food-borne intestinal trematode infections in the Republic of Korea. Parasitol Int 2002; 51: 129-154.

2. Chai JY. Metagonimus. In Xiao L, Ryan U, Feng Y eds, Biology of Foodborne Parasites. Food Microbiology Series. Boca Raton, USA. CRC Press. pp 427-443.

3. Seo BS, Lee SH, Cho SY, Chai JY, Hong ST, Han IS, Sohn JS, Cho BH, Ahn SR, Lee SK, Chung SC, Kang KS, Shim HS, Hwang IS. An epidemiologic study on clonorchiasis and metagonimiasis in riverside areas in Korea. Korean J Parasitol 1981; 19: 137-150.

4. Chai JY, Cho SY, Seo BS. Study on Metagonimus yokogawai (Katsurada, 1912) in Korea: IV. An epidemiological investigation along Tamjin River basin, South Cholla Do, Korea. Korean J Parasitol 1977; 15: 115-120.

5. Soh CT, Ahn YK. Epidemiological study on Metagonimus yokogawai infection along Boseong River in Jeonra Nam Do, Korea. Korean J Parasitol 1978; 16: 1-13 (in Korean). 
6. Ahn YK, Chung PR, Lee KT, Soh CT. Epidemiological survey on Metagonimus yokogawai infection in the eastern coast area of Kangwon province, Korea. Korean J Parasitol 1987; 25: 59-68 (in Korean).

7. Chai JY, Han ET, Park YK, Guk SM, Kim JL, Lee SH. High endemicity of Metagonimus yokogawai infection among residents of Samchok-shi, Kangwon-do. Korean J Parasitol 2000; 38: 33-36.

8. Chai JY, Huh S, Yu JR, Kook J, Jung KC, Park EC, Sohn WM, Hong ST, Lee SH. An epidemiological study of metagonimiasis along the upper reaches of the Namhan River. Korean J Parasitol 1993; 31: 99-108.

9. Kim CH, Kim NM, Lee CH, Park JS. Studies on the Metagonimus fluke in the Daecheong reservoir and the upper stream of Geum river, Korea. Korean J Parasitol 1987; 25: 69-82 (in Korean).

10. Park MS, Kim SW, Yang YS, Park CH, Lee WT, Kim CU, Lee EM, Lee SU, Huh S. Intestinal parasite infections in the inhabitants along the Hantan River, Chorwon-gun. Korean J Parasitol 1993; 31: 375-378.

11. Ahn YK, Ryang YS. Epidemiological studies on Metagonimus infection along the Hongcheon river, Kangwon Province. Korean J Parasitol 1988; 26: 207-213 (in Korean).

12. Kino H, Suzuki T, Oishi H, Suzuki S, Yamagiwa S, Ishiguro M. Geographical distribution of Metagonimus yokogawai and M. miyatai in Shizuoka Prefecture, Japan, and their site preferences in the sweetfish, Plecoglossus altivelis, and hamsters. Parasitol Int 2006; 55: 201-206.

13. Sohn WM. Fish-borne zoonotic trematode metacercariae in the Republic of Korea. Korean J Parasitol 2009; 47 (suppl): 103-113.

14. Chun SK. A study on Metagonimus yokogawai from Plecoglossus altivelis in the Miryang River. Bull Pusan Fish Coll 1960a; 3: 24-32 (in Korean).

15. Ahn YK. Lateolaborax japonicus, a role of the second intermediate host of Metagonimus yokogawai. New Med J 1983; 26: 135-139.

16. Chai JY, Sohn WM, Kim MH, Hong ST, Lee SH. 1991. Three morphological types of the genus Metagonimus encysted in the dace, Tribolodon taczanowskii, caught from the Sumjin River. Korean J Parasitol 1991; 29: 217-225.

17. Kim DG, Kim TS, Cho SH, Song HJ, Sohn WM. Heterophyid metacercarial infections in brackish water fishes from Jinju-man (Bay), Kyongsangnam-do, Korea. Korean J Parasitol 2006; 44: $7-13$.

18. Saito S, Chai JY, Kim KH, Lee SH, Rim HJ. Metagonimus miyatai sp. nov. (Digenea: Heterophyidae), a new intestinal trematode transmitted by freshwater fishes in Japan and Korea. Korean J Parasitol 1997; 35: 223-232.

19. Hwang JT, Choi DW. Metacercarial density of Metagonimus yokogawai in Plecoglossus altivelis in Kyungpook Province, Korea. Korean J Parasitol 1977; 15: 30-35.

20. Suh JW, Choi DW. Demonstration of Metagonimus yokogawai metacercariae from Plecoglossus altivelis in river Ahnseong, Kyungpook Province, Korea. Korean J Parasitol 1979; 17: 45-50.
21. Song CY. Studies on the Yokogawa's fluke Metagonimus yokogawai (Katsurada, 1912) in Korea. I. Geographical distribution of sweetfish and their infection status with Metagonimus metacercariae in Gangwon do. Chung-Ang J Med 1981; 6: 121-126 (in Korean).

22. Seo BS, Hong ST, Chai JY, Lee SH. Studies on Metagonimus yokogawai (Katsurada, 1912) in Korea: VI. The geographical distribution of metacercarial infection in sweetfish along the East and South coast. Korean J Parasitol 1982; 20: 28-32 (in Korean).

23. Song CY, Lee SH, Jeon SR. Studies on the intestinal fluke, Metagonimus yokogawai Katsurada, 1912 in Korea IV. Geographical distribution of sweetfish and infection status with Metagonimus metacercaria in south-eastern area of Korea. Korean J Parasitol 1985; 23: 123-138 (in Korean).

24. Sohn WM, Hong ST, Chai JY, Lee SH. Infection status of sweetfish from Kwangjung-stream and Namdae-stream in Yangyanggun, Kangwon-do with the metacercariae of Metagonimus yokogawai. Korean J Parasitol 1990; 28: 253-255 (in Korean).

25. Cho SH, Kim TS, Na BK, Sohn WM. Prevalence of Metagonimus metacercariae in sweetfish, Plecoglossus altivelis, from eastern and southern coastal areas in Korea. Korean J Parasitol 2011; 49: 161165.

26. Cho SH, Lee WJ, Kim TS, Seok WS, Lee T, Jeong K, Na BK, Sohn WM. Prevalence of zoonotic trematode metacercariae in freshwater fish from Gangwon-do, Korea. Korean J Parasitol 2014; 52: 399-412.

27. Sohn WM, Na BK, Cho SH, Lee SW, Choi SB, Seok WS. Trematode metacercariae in freshwater fish from water systems of Hantangang and Imjingang in Republic of Korea. Korean J Parasitol 2015; 53: 289-298.

28. Sohn WM, Na BK, Cho SH, Park MY, Kim CH, Hwang MA, No KW, Yoon KB, Lim HC. Prevalence of Clonorchis sinensis metacercariae in fish from water systems of Seomjin-gang (River). Korean J Parasitol 2017; 55: 305-312.

29. Yoon KB, Lim HC, Jeon DY, Park S, Cho SH, Ju JW, Shin SS, Na BK, Sohn WM. Infection status with Clonorchis sinensis metacercariae in fish from Tamjin-gang (River) in Jeollanam-do, Republic of Korea. Korean J Parasitol 2018; 56: 183-188.

30. Chai JY, Park JH, Han ET, Shin EH, Kim JL, Guk SM, Hong KS, Lee SH, Rim HJ. Prevalence of Heterophyes nocens and Pygidiopsis summa infections among residents of the western and southern coastal islands of the Republic of Korea. Am J Trop Med Hyg 2004; 71: 617-622.

31. Guk SM, Shin EH, Kim JL, Sohn WM, Hong KS, Yoon CH, Lee SH, Rim HJ, Chai JY. A survey of Heterophyes nocens and Pygidiopsis summa metacercariae in mullets and gobies along the coastal areas of the Republic of Korea. Korean J Parasitol 2007; 45: 205-211.

32. Park JH, Kim JL, Shin EH, Guk SM, Park YK, Chai JY. A new endemic focus of Heterophyes nocens and other heterophyid infections in a coastal area of Gangjin-gun, Jeollanam-do. Korean J Parasitol 2007; 45: 33-38. 